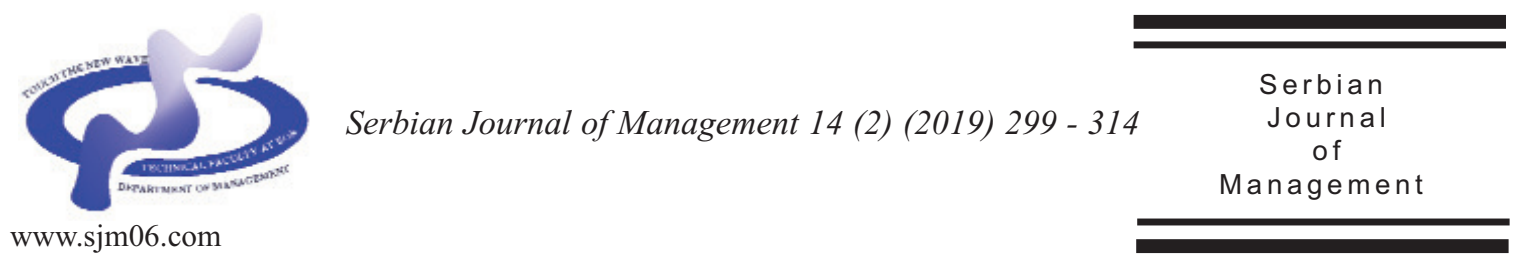

\title{
THE INFLUENCE OF A HUMAN RESOURCE STRATEGY TO THE FUNCTION OF HUMAN RESOURCE PROCESSES IN SMALL AND MEDIUM-SIZED ENTERPRISES (SMES)
}

\author{
Jaroslav Vrchota* and Petr Řehoř \\ University of South Bohemia in Česke Budějovice, \\ Studentska 13, Česke Budějovice, Czech Republic \\ (Received 20 November 2018; accepted 12 August 2019)
}

\begin{abstract}
The human resources management strategy is currently considered one of the most important elements of a corporate strategy, mainly because its main goal is to work with people as the most important capital of each organization. Without people, the organization is unable to meet its goals. A well-prepared HR strategy and an action plan for its implementation enables an organization to effectively plan and manage individual processes to support the organization's goals and to respond flexibly to any change.

The paper deals with a sub-research of the management of small and medium-sized enterprises in the Czech Republic. It is focused on the use of HR strategy in SMEs management and the assessment of the significance of HR process. Data were gathered as questionnaires and interviews from 290 enterprises operating in the Czech Republic. The research was done in 2016. Unfortunately, the HR strategy is defined by $2 / 5$ of small and medium-sized enterprises in the Czech Republic. Based on statistics analysis, the authors proved a weak relation between HR strategy and the function of human resource processes.
\end{abstract}

Key words: strategy, human resources, management, process, SMEs.

\section{INTRODUCTION}

Small and medium-sized enterprises (SMEs) play a significant part in economic activity through employment, innovation and growth (Floyd \& McManus, 2005; Mihajlović, 2014), acting as a supplier of goods and services to large organization and any lack of product quality could adversely affect the competitive ability of the larger

* Corresponding author: vrchota@ef.jcu.cz

DOI: $10.5937 /$ sjm14-19588 
organizations (Baba et al., 2006). In the European Union, SMEs account for $99.8 \%$ of companies, generate $60 \%$ of GDP and employ $70 \%$ of private sector workers (European Commission, 2018).

The OECD estimates that $99.8 \%$ of enterprises in the enlarged EU are SMEs (OECD, 2005). Another calculation estimates that only 250.000 of the 25 million firms in Europe employ more than 250 employees (European Commission, 2015). This numerical importance of smaller firms as a provider of employment coupled with their material status should mean they are necessarily of interest to those concerned with HRM (Forth et al., 2006).

Practical argument for studying HRM (Human Resource Management) in smaller firms is that the strategic significance of HRM in contributing to the viability and success of organisations finds added importance in this context; smaller firms tend to be labour intensive, and the additional value added by each individual employee is more transparent and telling (Paauwe, 2004). Indeed, sound management of employees can be a critical factor determining the survival and growth of smaller firms (Cafferkey et al., 2013).

In the contemporary business environment, human resources (HR) is an indispensable input for organizational effectiveness. Hence, an effective management of human resources has an important role to play in the performance and success of organization (Chung et al., 2008).

Rapidly changing markets and increasing global competition are forcing many businesses to re-examine their activities and reprioritize their operations (Ok, 2011). Many organizations strive to find better ways to become competitive in the dynamic environment (Susomrith \& Brown, 2013) by planning restructuring and developing flexibility.

According to Boxall and Purcell (2008) HRM are those activities associated with the management of work and people in firms. As noticed by Charvát (2006), human resources are the only source with which we work together, communicate, and pass on information about other sources in an enterprise. Human resources are strategic to basic viability as well as advantage (Boxall, 1998).

HRM helps direct employees' attention and behavior toward the sustainability goals of the firm through its overall approach and the individual policies and practices that embody that approach (e.g., Egri \& Hornal, 2002; Ramus \& Steger, 2000). The modern HR Processes are grouped into logical HR areas as they provide the value added to the internal and external clients. The main HR Process Areas are: Recruitment and Staffing, Compensation and Benefits, Training and Development, Career Development, Talent Management, Leadership Development, HR Controlling (Robbins \& Coulter, 2017; Volek \& Novotná, 2016; Donnelly et al., 2007).

HR studies should link between classic HR functions (recruitment, selection, training, performance management, and compensation) and business strategy which cover the role of industry on these functions and explain how these functions work (Batt \& Banerjee, 2012).

HRM activities represent an increasingly costly component of the operations of all businesses (Brown, 2011; Susomrith \& Brown, 2013). HRM is both a means and an end to realizing a firm's strategic objectives (Huselid et al., 2005). As a means, HRM policies and practices help direct employee mind-sets and actions toward achieving the sustain-ability goals of the firm (Egri \& 
Hornal, 2002; Milliman \& Clair, 1996).

HR managers have traditionally been responsible for selecting, hiring, training, and managing compensation of the workforce; they are now expected to be more flexible, responsive, and efficient in these activities, as well as contribute to the strategic decisions of their organizations (Edralin, 2008; Nankervis \& Stanton, 2011; Mihajlović, 2016; Ulrich et al., 2008). The various HR practices within a given organization should complement each other with a view to improving employee performance and enhancing the organization's core competitive advantage (Stanton \& Nankervis, 2011). HRM is also one of the the key functions in the development and implementation of strategic process (Sondhi \& Nirmal, 2013).

Strategic management is intended to ensure that the business needs of the organization and the individual and collective needs of its employees can be met by practical human resources policy (Armstrong, 2002). By Koubek (2007), strategic management of an organization is linked to a personal strategy. The objectives incorporated into the human resource strategy are achieved by a real activity, real efforts - strategic management of human resources. HR policy follows the HR strategy. It focuses on the implementation of the strategy and the HR procedures defining the steps of different processes in the area of HR management (Hrzán, 2007).

Although strategic human resource management (SHRM) as a discipline has evolved rapidly and has demonstrated its relevance in the past few decades, inconsistent results concerning the way in which human resources contribute to achieving strategic objectives are still common (Guest, 2011; Lengnick-Hall et al.,
2009; Woodrow \& Guest, 2014). Specifically, Huselid \& Becker (2011) criticize most studies for focusing on HR content.

Strategic HRM is a link between HRM and strategic management processes of a company. Strategic means that HR activities should systematically design and deliberately connected to an analysis of business and its context (Schuler et al., 2001). The strategic management of human resources, therefore, through HR interventions such as employee involvement, suggestion schemes, and knowledge sharing is seen as a value-added HR function (Cooke \& Saini, 2010). The concept of HRM strategy concludes that individual HR functions, if viewed in isolation, tend to lack congruency in most organizations (McEvoy \& Buller, 2013).

One of the main options available is to continue to focus on improvements in human capital and innovation as sources of competitive advantage (Bae et al., 2003). HRM strategy is concerned with managing people (through recruitment, development, appraisal, compensations, and work systems) in order to achieve the overall organizational objectives (Edralin, 2008).

An HRM strategy is usually defined as the strategic orientation explicitly or implicitly adopted by organizations to manage their human resources. If it is consistently designed, the HRM strategy provides guiding principles for other HRM initiatives, and assures management coherence (GarciaCarbonell et al., 2016). An HRM system, on the other hand, reflects the co-ordination of a specific set of practices designed to implement the HRM strategy (MartínAlcázar et al., 2005). Success in the implementation of an HRM strategy requires that the system is implemented to be 
distinctive, consensual and consistent (Bowen \& Ostroff, 2004). For this to occur, the HRM system should not only be designed on the basis of the vertical (external fit) and horizontal (internal fit) conditions, but should also be communicated adequately (Garcia-Carbonell et al., 2016).

Empirical research on HRM in SMEs shows that there is a great diversity of HRM practices among small businesses and firm size is a major determinant of their adoption and formalization (Marlow, 1998; Wager, 1998; Cassell et al., 2002). Bayo-Moriones \& Merino-Diaz de Cerio's research (2001) in the Spanish context also provides evidence about variations in HRM practices according to firm size (Urbano \& Yordanova, 2008). The literature reveals that most studies examining the relationship between HRM and organizational performance (Gerhart et al., 2005; Arthur, 1994; Ericksen \& Dyer 2005; Wright et al., 2005).

Khatri (2000) examined the links between strategy and HR practices, and HR practices and firm performance. Results showed that overall strategy affects HR practices, HR practices have a direct effect on organizational performance, and business strategy moderates the relationship between HR practices and organizational performance. Huang (2000) found that firms with higher levels of performancewere more likely to adopt certain SHRM practices, such as planning, staffing, appraisal, compensation, and training and development. Richard \& Johnson (2001) found that SHRM effectiveness significantly reduces turnover, Harris \& Ogbonna (2001) tested the relationship between SHRM and performance.

Vlachos (2008) used a sample of food managers in Greece to assess the relationship between HR practices (job security, selective hiring, self-managed teams and decentralization of decision making, compensation policy, extensive training, and information sharing) and organizational performance. He found a relationship between HR practice and organizational performance for all practices except job security. The alignment between the business and HRM strategy was the key factor of success for organizations. Strategy fit could also moderate the relationship between HRM effectiveness and labor productivity (Wang \& Shyu, 2008). Abdul-Halim et al., (2016) examine the relationships among six types of HRM strategies with three categories of outsourcing HR activities to reduce HR labour costs. No study has ever discussed the influence of HRM to human resource processes regarding their efficient function.

\section{EXPERIMENTAL (RESEARCH)}

The aim of the paper is to assess the influence of a defined human resource strategy (HRS) to the function of human resource processes in small and mediumsized enterprises (SMEs) in the Czech Republic.

The authors set null hypothesis $(\mathrm{H} 0)$ that the function of human resources processes is at the same level for SMEs, regardless of whether they have a defined human resource strategy or not. The alternative hypothesis (HA) says that the management of the human resources process in the MPS is better in enterprises with a defined human resource strategy. The data were obtained from a questionnaire survey in 2016. There were a total of 290 small and medium-sized enterprises. After verifying this hypothesis, the sample was subsequently subdivided into six categories by business type: trade, 
transport, agriculture, manufacturing, services and construction. In each business sector, $\mathrm{H} 0$ was verified with HA because it is possible to anticipate the different impact of HRS on process management in different business sectors (for example, manufacturing enterprises compared to services).

The authors set a null hypothesis ( $\mathrm{H} 0)$ that the function of human resource processes is at the same level for SMEs, regardless of whether they have a defined human resource strategy (HRS) or not. The alternative hypothesis (HA) says that the function of the human resource process in the SMEs with a defined human resource strategy is at a higher level than in enterprises without HRS. The data were obtained from a questionnaire survey in 2016. There were a total of 290 small and medium-sized enterprises. After verifying this hypothesis, the sample was subsequently subdivided into six categories by business type: trade, transport, agriculture, manufacturing, services and construction. In each business sector, $\mathrm{H} 0$ was verified because it is possible to anticipate the different impact of HRS on the function of human resource processes in different business sectors (for example, manufacturing enterprises compared to services).

The function of $\mathrm{HR}$ processes in an enterprise was rated by the managers of SMEs, ranging from 1 to 9 points (1 point the HR processes are working effectively, HR policy is fully fulfilled, 9 points - HR processes do not work, HR policy is not fulfilled). The data were tested using twosample Wilcoxon test (Freund et al., 2010; Freeman et al., 2017) and its asymptotic version. It is a non-parametric two-sample test, often used when we do not assume that the data are normal. A slight abnormality of data of samples larger than 30 does not have a significant influence to the results of the test (Freeman et al., 2017; Devore, 2015).

If are $\mathrm{x}_{1}, \ldots, \mathrm{x}_{\mathrm{n}}$ a $\mathrm{y}_{1}, \ldots, \mathrm{y}_{\mathrm{m}}$ two independent random samples of two continuous distributions in which the distribution function might differ by a translation only. $\mathrm{x} 0.50$ and $\mathrm{y} 0.50$ are the median of the first and the second distribution. A hypothesis of the same distribution functions of both distributions is always tested, saying that the medians are equal. The alternative hypothesis says that the first median $\mathrm{x}_{0.50}$ of SMEs with a defined strategy is greater than the second (Budíková et al., 2010; Freund et al, 2010; Keller, 2014).

The first step arranges all $(n+m)$ values of $\mathrm{x}_{1}, \ldots, \mathrm{x}_{\mathrm{n}}$ and $\mathrm{y}_{1}, \ldots, \mathrm{y}_{\mathrm{m}}$ in ascending order by the size. The whole test is processed electronically by the Statistika ver.10 software, this step is not recorded as it is a simple operation only. The next step gives the sum of values of $x_{1}, \ldots, x_{n}$ marked as $T_{1}$. The sum of values in order of SMEs without SHR $_{1}, \ldots, \mathrm{y}_{\mathrm{m}}$ is marked as $\mathrm{T}_{2}$. Further, the test statistics is calculated for $\mathrm{U}_{1}$ and $\mathrm{U}_{2}$, while $\mathrm{U}_{1}+\mathrm{U}_{2}=\mathrm{mn}$ still applies (Budíková et al., 2010; Spellman \& Whiting, 2014). If the statistics of $\min \left\{\mathrm{U}_{1}, \mathrm{U}_{2}\right\} \geq$ tabelled critical value for the ranges of both samples and the level of significance, the null hypothesis of equality of both samples is rejected at the significance level of $\alpha=0.05$.

As $n, m$ in both samples in all tests are bigger than 30, Mann-Whitney test (asymptotic varsion of Wilcoxon test) is used. The test is used for such samples if $n$, $\mathrm{m}$ are bigger than 30 and $\mathrm{U}^{\prime}{ }_{1}=\min \left\{\mathrm{U}_{1}\right.$, $\mathrm{U}_{2}$ \} (Walker, 2010; Meloun et al., 2012). 
The range of critical values of the right-side alternative $\mathrm{W}=<\mathrm{k}_{2}, \mathrm{n}>$ and non-negative values of $\mathrm{k}_{1}$ and $\mathrm{k}_{2}$ are exactly quoted by scientific publications. $\mathrm{H}_{0}$ is rejected at the significance level of $\alpha$, if $\mathrm{U}_{0} \in \mathrm{W}$ (Freund et al., 2010; Freeman et al., 2017). The test results confirm the difference in curve translation of SMEs with and without HRS.

\section{RESULTS AND DISCUSSION}

The human resource (HR) strategy builds on the organization's overall strategy. This strategy identifies a long-term plan designed to achieve the human resources and human capital management and human development objectives in the organization. It is one of the outcomes of strategic management in the field of human resource management. It helps to unify and regulate the behaviour and actions of all people. It also allows meaningful planning and management of all work with human resources. The HR strategy's goal is to develop, shift staff in relation to their employment, to their work roles that meet the needs of the organization. Organizations must have the right people at the right time.

The HR strategy includes all HR processes, programs and measures relating to the employment of people, recruitment, selection and stabilization of workers, their further education and development, remuneration or career growth. In addition, this strategy must also include ideas on ways and means of achieving the goals. In the Czech Republic, only about $40 \%$ of SMEs have a defined HR strategy (CzechInvest, 2016).

Using two-sample Wilcoxon test (MannWhitney $U$ test) at the significance level of $\alpha=0.05$, we tested the hypotheses of $\mathrm{H}_{0}=\mathrm{x}_{0.50}-\mathrm{y}_{0.50}=0$, supposing that the function of HR processes is the same in small and medium-sized enterprises and it does not depend on a defined HR strategy, and $\mathrm{HA}=\mathrm{x}_{0.5}>\mathrm{y}_{0.50}$, supposing that the function of HR processes is better in enterprises with HRS. In both hypotheses, $x$ $=$ the enterprises with HRS and $\mathrm{y}=$ the enterprises without HRS.

As shown by Table 1, p-value is 0.0004 . It is lower than $\alpha$, so the null hypothesis is rejected, in favour of the alternative, although the $Z$ value is negative. It is possible to confirm, that SMEs with efficient HR processes have a defined HR strategy.

The results are shown by a box-plot (Figure 1), revealing that both samples of enterprises have the same minimal and maximum values, as there were always enterprises rating the processes as nonfunctional (9) or well-functioning (1). The median of the enterprises with HRS amounted to 5, which is 1 point better than the enterprises without HRS. The enterprises with HRS have a mean quartile value of 4 to 6 points compared to the mean quartile of non-HRS enterprises ranging between 5 and 6 .

Figure 2 shows the distribution of answers in the sample of 290 small and medium-sized enterprises. Almost $40 \%$ of the managers reported that they have a defined HRS. Most frequently, they rated the function of HR processes with 5-6 points (27 and 23 answers). There were $61 \%$ of SMEs without a defined HRS and the peak of the curve showing the function of HR processes shows the value of 5.9, compared to 5 in enterprises with a defined HRS.

Further, $\mathrm{H}_{0}$ and $\mathrm{HA}$ were verified for the enterprises classified by type of business into six groups. The tests were the same as for the 
Table 1. Mann-Whitney U test

\begin{tabular}{llllll}
\hline SME & With HRS & Without HRS & U & Z & p-value \\
\hline Function of HR processes & 14122.50 & 28072.50 & 7567.50 & -3.53 & 0.000412 \\
\hline
\end{tabular}

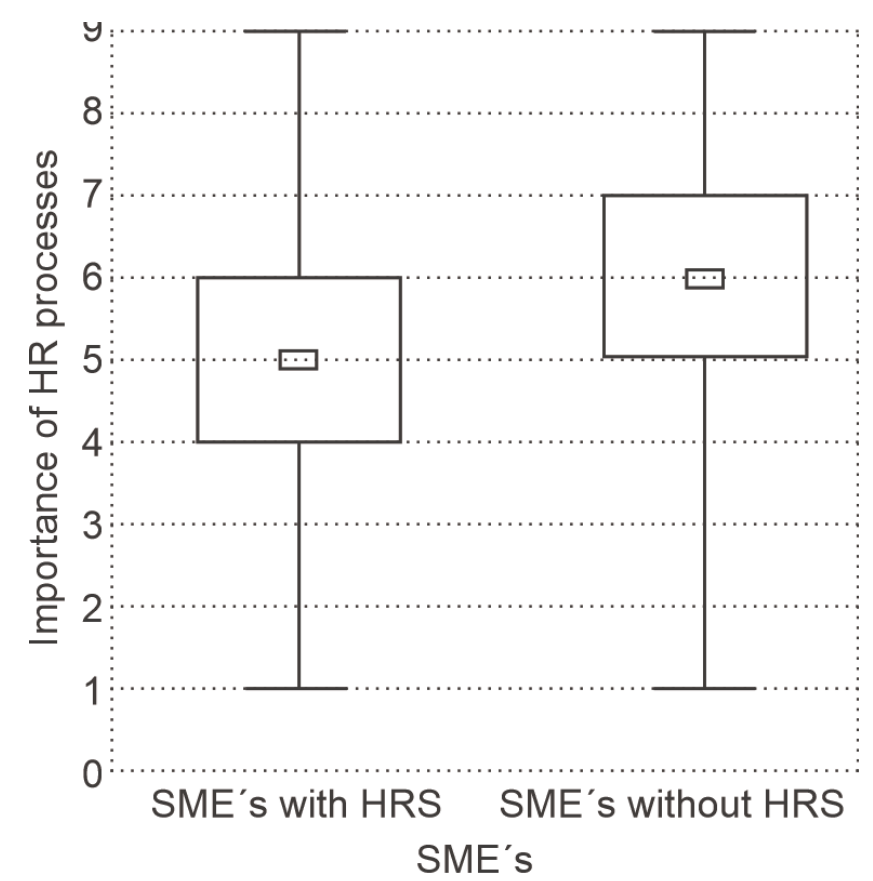

Figure 1. Comparison of SME's with and without HRS
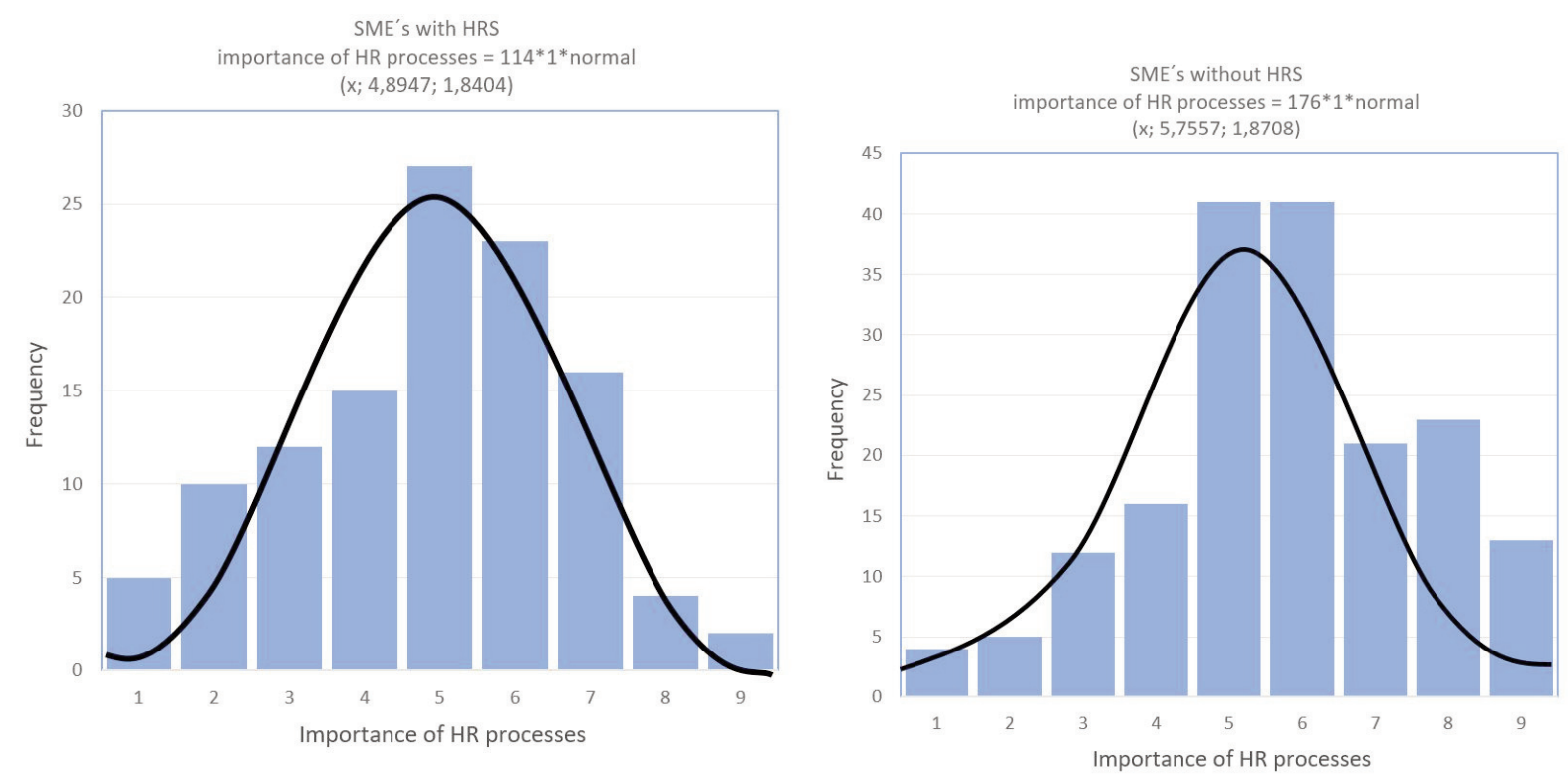

Figure 2. The distribution of answers in SME's 
whole sample of 290 enterprises. The results of the analysis are clearly summarized in Table 2. The agricultural enterprises were excluded from the statistics due to a low number of observations. As shown in Table 2, p-value was not close to zero in two cases of the transport enterprises (0.189784) and in the enterprises dealing with services (0.666926). In all other cases, it was possible to reject the null hypothesis in favour of the alternative, similar to the whole sample, although $\mathrm{Z}$ value was also negative. The results are clearly shown in box-plots below (Figures 3-5).

The left part of figure 3 showing the service enterprises reveals that the enterprises without HRS have a greater variance with a minimum of 1 and a maximum of 9 and the mean quantile ranging from 5.0 to 7.0 points. Similarly, the median is 6.0 and the value is similar to enterprises using HR strategy. Interestingly, the enterprises in this business did not score 9 points. The right box-plot shows the values for manufacturing enterprises. Both samples have the same minima and maxima, of 1.0 and 9.0 points. The median of the enterprises with a strategy is 5, compared to 6 in the enterprises without HRS.

A left part of Figure 4 revealed the significant difference between the enterprises with HRS, compared to those without HRS in the area of trade. The median of the enterprises with a strategy is 5, compared to 6.0 in the enterprises without
HRS. It is also interesting that the variance ranges between 1.0 and 7.0 as the maximum in the enterprises with HRS, compared to a wide variance if enterprises without HRS.

Also, average values of $25 \%-75 \%$ in enterprises with HRS range between 4.0-6.0 compared to greater freedom for nonstrategy enterprises where the average quantile is between 5.0 and 7.0. Graphically, Wilcoxon test was confirmed here, with the p-value close to zero. The right part of the Figure 4 shows the values for the transport enterprises with significant differences for both groups. Enterprises with HRS have a median of 5.5 points. The median of nonstrategic enterprises is lower by 1.5 points. Businesses without a strategy had a wider range of significance, with responses ranging from 2 points to 9 but with a smaller mean value of a quantile, ranging from 5.0 points to 8.0 points.

Figure 5 shows agricultural enterprises, which are illustrated here only for sake of the completeness of the data. As mentioned above, they were excluded from tested statistics due to a low number of respondents under 20. The right plot shows construction enterprises. Interestingly, although the median value for HRS enterprises is 5 points, the median quartile is from 2 to 6 points. Six points are also the maximum level of the variance for HRS enterprises. On the other hand, the enterprises without HRS report a standard variance from 1 to 9 with a median of 6 points.

Table 2. Mann-Whitney $U$ test for enterprises according the industry area

\begin{tabular}{llllll}
\hline Industry area & With HRS & Without HRS & $\mathbf{U}$ & $\mathbf{Z}$ & p-value \\
\hline Service & 948 & 1680 & 570 & -0.430371 & 0.666926 \\
Transport & 42.5 & 128.5 & 21.5 & -1.311220 & 0.189784 \\
Agriculture & Low number of data & & & & \\
Manufacturing & 1359 & 2557 & 693 & -2.05804 & 0.039587 \\
Building industry & 131 & 397 & 65 & -1.98380 & 0.047279 \\
Trade & 549 & 1104 & 249 & -2.36784 & 0.017893 \\
\hline
\end{tabular}



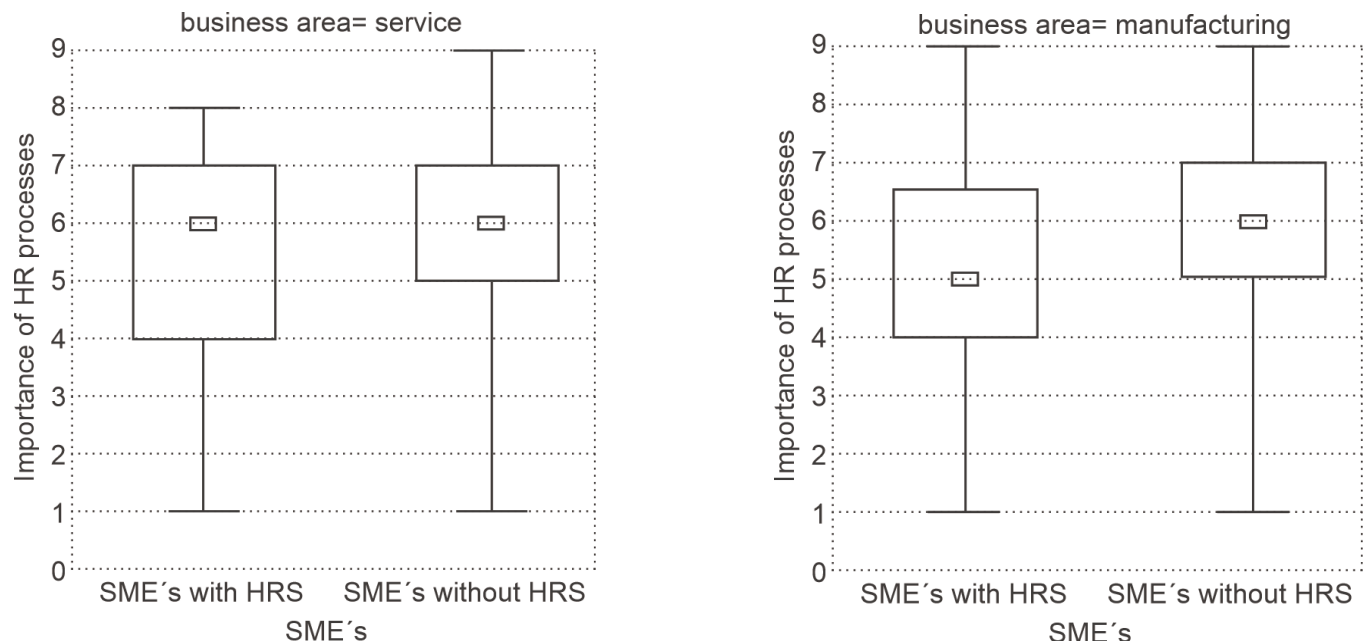

Figure 3. Median and interval of data layout in strategy and no-strategy SME's from sector service (left) and manufacturing (right
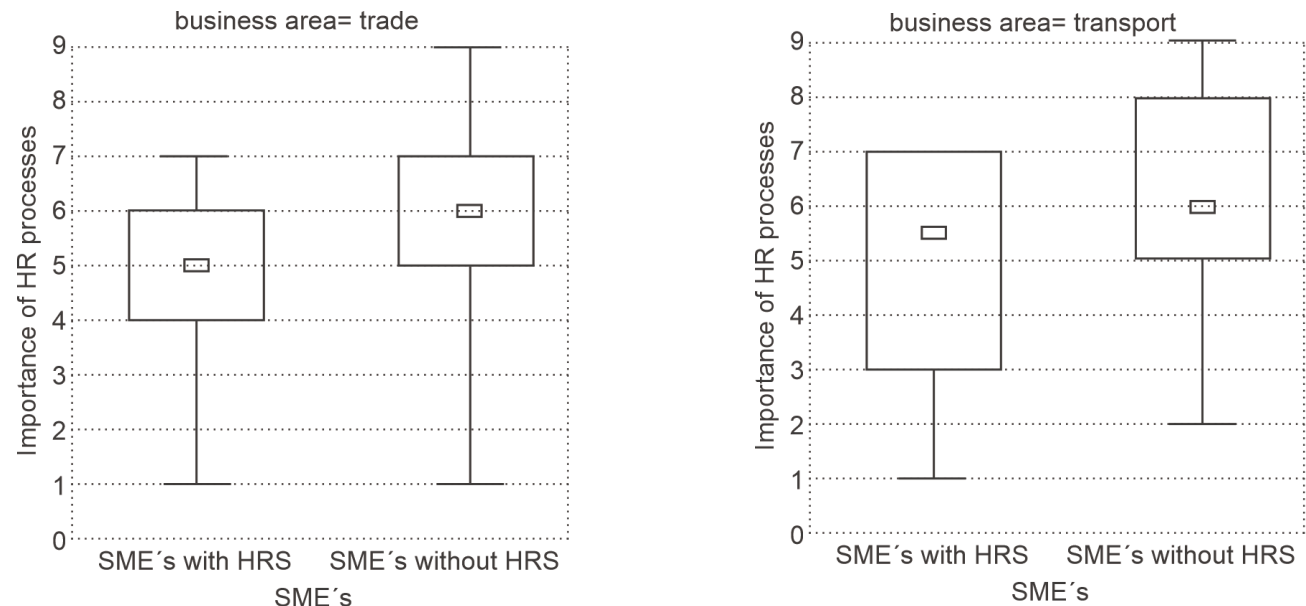

Figure 4. Median and interval of data layout in strategy and no-strategy SME's from sector trade (left) and transport (right)
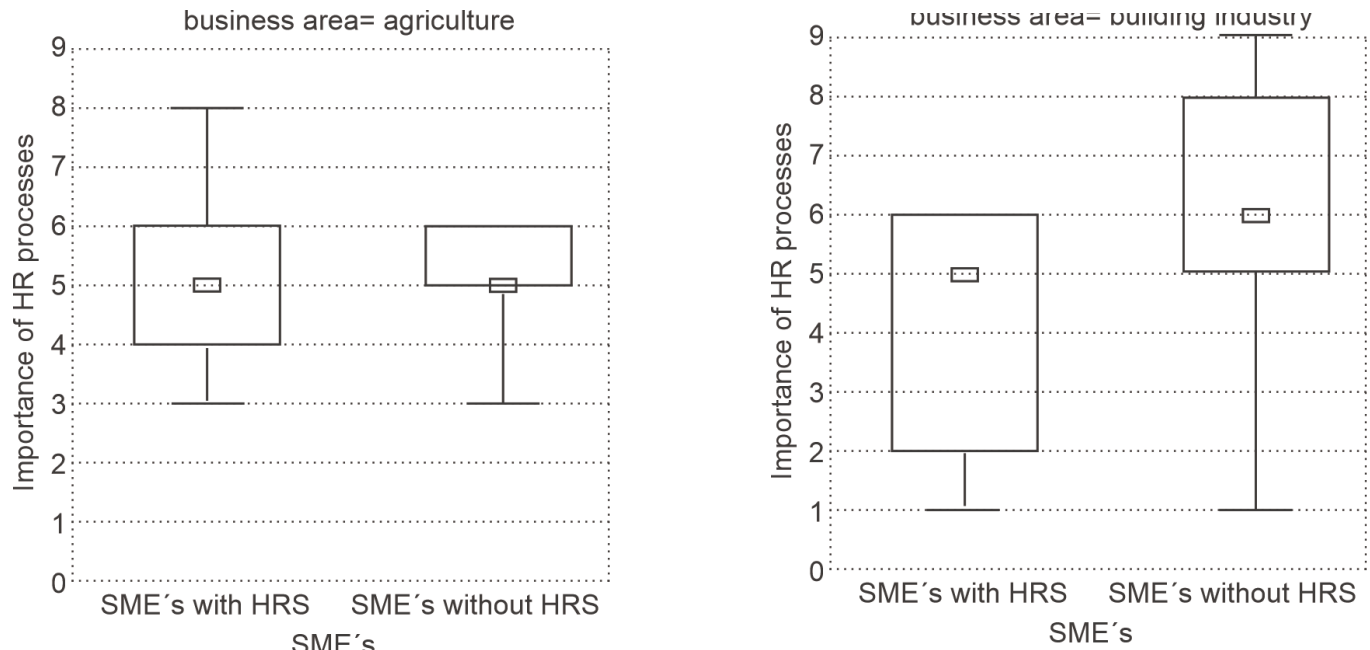

Figure 5. Median and interval of data layout in strategy and no-strategy SME's from sector agriculture (left) and building industry (right) 


\section{CONCLUSION}

In today's highly competitive environment, human capital is becoming a key factor in success. People are the greatest wealth of an organization and create its basic competitive advantage. The labour market has changed a lot in recent years and it is constantly changing and developing. The changes are related to a number of new trends. Linking the processes of HR management with marketing, public relations, corporate strategy, and vision is widely discussed. The HR strategy is an essential part of corporate strategy. Its specific aims are based on the goals of the enterprise. The HR strategy thus contributes to the systematically managed organization development, together with the goals of other departments. The HR strategy clearly sets out what and how to change HR processes so that organizations can best achieve their goals.

Many small businesses have less than five employees; and therefore they believe the role of human resources in their business is minor. HR is actually very important in small businesses because of the significant impact one or a few employees can have on the business (Sheehan \& Cooper, 2011). Although we could expect HR management to be done systematically in SMEs, it appears that even today, only $40 \%$ of the enterprises in the Czech Republic are managed using a HR strategy. Other enterprises either do not have an HR strategy at all or they do not follow it. Managers evaluate the HRM process between 5-6, which is the top on the 9-point scale. According to Holatova et al. (2018) The Human Resource Management process works at $69 \%$ in SMEs, ranks 5 th among other processes. Production is first, followed by quality management and sales.
In particular, small businesses do not have a separate personnel department, so the manager manages working with people, so the operation of this process is not higher.

The HR strategy is present and followed mostly by such enterprises for which it is important to employ and keep high-quality employees and to care for their development (Pech \& Vaněček, 2018). HR issues are steadily increasing in all types of organizations, young workers want more freedom and desire a faster career ( $\mathrm{Ng}$ et al., 2010; Westerman et al., 2011). Small and medium-sized enterprises have their own specificities in all areas of existence and of course, in their human resource management, too. Perhaps the most striking characteristic is that small businesses rarely have an HR department or an HR specialist. HR strategy of small enterprises is one of the least researched areas (Mankelow, 2008). Small firms also need HR managers. Performance and effective strategic human resource management enables the entrepreneurs to improve the quality of their production. The owner, the bearer and the implementer of HR work and strategy is usually the owner (manager) of the enterprise. Because such person is mostly an expert in other areas, they concentrate the forces primarily on production, sales, technology, and neglect the importance of the human factor in the organization. In addition, a small business is more vulnerable to changes in the external environment; it has no long-term resources and reserves. Each worker's error is more visible and more threatening the reputation and competitiveness of the organization with their customers and business partners.

The frequent argument of managers for underestimating HR says that the organization needs to be very flexible and 
cannot create any strategies, including HR. However, it is necessary for the owners of these organizations to focus their attention on human resources, acquire the necessary knowledge and skills of strategic management and create an HR concept that will increase the long-term competitiveness of the organization and also increase the satisfaction of the employees themselves. Using statistical hypothesis testing, the dependence between a defined HR strategy and the functioning of HR processes in all 290 SMEs of the sample was confirmed. The authors have confirmed the hypothesis that if an enterprise has an HR strategy, it achieves better functioning in HR processes. The hypothesis was not confirmed only for the service and transport enterprises. Such conclusion supports the idea that a properly defined HR strategy is essential for any organization as without a strategy efficient HR processes and HR development are impossible.

Therefore, the HR strategy makes it possible to plan and manage all work with human resources better, taking into account the organization's overall strategy. This strategy defines both the need for workers while defining the coverage of this need and also includes the use and management of workforce. The strategy helps to determine what and how to change human resources management in order for organizations to best achieve their goals. Part of the HR strategy should also be an action plan that describes how to achieve the goals. The effective HR process management is an excellent tool to introduce, manage and improve procedures and policies in human resources. Managers are responsible for the design, development and re-design of the HR processes as the HR strategy can be implemented. HRM practices must develop employee's skill, knowledge and motivation such that employees behave in ways that support the implementation of particular business strategy (that says Bowen \& Ostroff, 2004). Thus for higher performance it is necessary to develop HRM policy that align the business strategy and HRM systems.

As the human factor is getting more important in business, the importance of long-term HR strategy will grow too. Its quality will also depend on the ability of an enterprise to compete in a competitive fight for good quality human resources. Each business should set its own HR strategy and should have its HR policy. Only the correct relation of the HR strategy with the organization's entire strategy can lead to long-term success (Holátová et al., 2018). To make the creation of the HR strategy effective, it should be a recurring process. Its location and importance will depend primarily on the importance of organizing human resources to achieving long-term business goals and creating the overall market value of an organization. Growth in the importance of human capital is also due to easier access to financial capital and material resources.

HR departments must become more strategic with limited resources, which is a trend that has been shown to exist competitively. To achieve this objective, HR managers turn to outsourcing. The growth in HR outsourcing has encouraged research into the best strategic conditions for externalization of HRM activities (as says Kinange \& Murugaiah, 2011; Sheehan \& Cooper, 2011). Several studies have documented this trend towards the outsourcing of HR functions (Chiang et al., 2010; Gilley et al., 2004; Kinange \& Murugaiah, 2011). A large number of HR 
functions can be shifted to line management (that confirms Larsen \& Brewster, 2003).

\section{Acknowledgement}

This article has been presented with the financial support of the project GAJU 053/2016/S.

\section{References}

Abdul-Halim, H., Che-Ha, N., Geare, A., \& Ramayah, T. (2016). The pursuit of HR outsourcing in an emerging economy. Canadian Journal of Administrative Sciences, 33 (2), 153-168.

Armstrong, M. (2002). Human resource management. Praha: Grada.

Arthur, J. B. (1994). Effects of human resource systems on manufacturing performance and turnover. Academy of Management Journal, 37, 670-687.

Baba, Deros, Yusof, S. M., Azhari, \& Salleh. (2006). A benchmarking implementation framework for automotive manufacturing SMEs. Benchmarking: An International Journal. https://doi.org/10.1108/14635770610676272

Bae, J., Chen, S.-J.J., Wan, T.W.D., Lawler, J.J., \& Walumbwa, F.O. (2003). Human resource strategy and firm performance in Pacific Rim countries. International Journal of Human Resource Management, 14 (8), 1308-1332.

Batt R., \& Banerjee M. (2012) The scope and trajectory of strategic HR research: evidence from American and British journals. The International Journal of Human Resource Management, 23 (9), 1739-1762.

Bowen, D.E., \& Ostroff, C. (2004).

\title{
УТИЦАЈ СТРАТЕГИЈЕ УПРАВЉАЫА ЉУДСКИМ РЕСИМА НА ФУНКЦИЈУ ПРОЦЕСА ЉУДСКИХ РЕСУРСА У МАЛИМ И СРЕДЫИМ ПОДУЗЕһИМА (МСП)
}

\author{
Jaroslav Vrchota, Petr ̌̌ehoř
}

\section{Извод}

Стратегија управљања људским ресурсима тренутно се сматра једним од најважнијих елемената корпоративне стратегије, углавном зато што је њен главни циљ рад са људима као најважнијим капиталом сваке организације. Без људи организација није у стању да испуни своје циљеве. Добро припремљена стратегија људских ресурса и акциони план за њено спровођење, омогућава организацији да ефикасно планира и управља појединим процесима како би подржала своје циљеве и флексибилно реаговала на било какве промене.

Рад се бави истраживањем управљања малим и средњим предузећима у Чешкој и фокусиран је на употребу стратегије управљања људским ресурсима у управљању МСП-има и процену значаја процеса управљања људским ресурсма. Подаци су прикупљени коришћењем упитника и интервјуа у 290 предузећа која послују у Чешкој Републици. Истраживање је спроведено током 2016. На основу добијених резултата, може се закључити да хажалост, стратегију управљања људским ресурсима има свега $2 / 5$ малих и средњих предузећа у Чешкој. На основу статистичких анализа, аутори су доказали слабу повезаност између стратегије и функције људских ресурса.

Кључне речи: стратегија, људски ресурси, управљање, процес, МСП. 
Understanding HRM-firm performance linkages: The role of the strength of the HRM system. Academy of Management Review, 29 (2), 203-221.

Boxall, P. (1998). Achieving competitive advantage through human resource strategy: Towards a theory of industry dynamics. Human Resource Management Review, 8 (3), 265-288.

Boxall, P., \& Purcell, J. (2008). Strategy and human resource management. London: Palgrave MacMillan.

Brown, P. (2011). The power of HR outsourcing. Strategic HR Review, 9 (6), 27-32.

Budíková, M., Králová, M., \& Maroš, B. (2010). Guide to basic statistical methods. Praha: Grada Publishing.

Cafferkey, K., Harney, B., \& Teck, P. E. (2013). Human capital in Malaysian SMEs: HR practices, uniqueness, and value. In Effective Human Resources Management in Small and Medium Enterprises: Global Perspectives (s. 28-43). https://doi.org/10.4018/978-1-4666-47312.ch002

Cassell, C., Nadin, S., Gray, M., \& Clegg, C. (2002) Exploring human resource management practices in small and medium sized enterprises. Personnel Review, 31, 671-692.

Cooke, F.L., \& Saini, D.S. (2010). (How) Does the HR strategy support an innovation oriented business strategy?. Human resource management, 49 (3), 377-400.

CzechInvest. (2016) Region report n. 1. Available

at:

https://www.czechinvest.org/cz/OCzechInvestu/Ke-stazeni/Materialy-vcestine

Devore, J. L. (2015). Probability and Statistics for Engineering and the Sciences. Boston, MA: Brooks Cole.
Donnelly, J.H., Gibson, J.L, \& Ivancevich, J.M. (2007). Management. Praha: Grada.

Edralin, D.M. (2008). Innovative human resource management (HRM) practices as predictors of employee job involvement and organizational commitment. Asian Journal of Technology Innovation, 16 (2), 67-81.

Egri, C.P. \& Hornal, R.C. (2002). Strategic environmental human resource management and perceived organizational performance: An exploratory study of the Canadian manufacturing sector. In S. Sharma and M. Starik (Eds.), Research in corporate sustainability: The evolving theory and practice of organizations in the natural environment. Northhampton, MA: Edward Elgar Publishing.

Ericksen, J., \& Dyer, L. (2005). Towards a strategic human resource management model of high reliability organization performance. International Journal of Human Resource Management, 16 (6), 907928.

European Commision. (2015).User guide to the SME Definition [Online]. Luxembourg: Publications Office of the European Union. Available at: https:/ec.europa.eu/docsroom/documents/15 582/attachments/1/translations/en/renditions /native

European Commision. (2018). European Innovation Scoreboard [online]. Luxembourg: Publications Office of the European Union. Available at: http://ec.europa.eu/growth/industry/innovati on/facts-figures/scoreboards_en

Floyd, D., \& McManus, J. (2005). The role of SMEs in improving the competitive position of the European Union. European Business Review. https://doi.org/10.1108/09555340510588011 Forth, J., Bewley, H., \& Bryson, A. 
(2006). Small and medium-sized enterprises:

Findings from the 2004 Workplace

Employment Relations Survey.

Freeman, J., Shoesmith, E., Sweeney, D., Anderson, D., \& Williams, T. (2017). Statistics for Business and Economics. Place of publication not identified: Cengage Learning EMEA.

Freund, R.J., Wilson, W.J., \& Mohr, D.L. (2010). Statistical methods. Amsterdam: Elsevier.

Garcia-Carbonell, N., Martin-Alcazar, F., \& Sanchez-Gardey, G. (2016). The views of Spanish HR managers on the role of internal communication in translating HR strategies into HRM systems. European Management Journal, 34 (3), 269-281.

Gerhart, B., \& Fang, M., (2005). National culture and human resource management: Assumption and evidence. International Journal of Human Resource Management, 16 (6), 971-986.

Gilley, K.M., Greer, C.R., \& Rasheed, A.A. (2004). Human resource outsourcing and organizational performance in manufacturing firms. Journal of Business Research, 57, 232-240.

Guest, D.E. (2011). Human resource management and performance: still searching for some answers. Human Resource Management Journal, 21 (1), 3-13.

Harris, L., \& Ogbonna, E. (2001). Strategic human resourcemanagement,market orientation, and organizational performance. Journal of Business Research, 51 (2), 157-166.

Hrzán, J. (2007). Personnel strategy on the European market. Cit. online: http://exportniklub.czechtrade.cz/dokumenty /exportniklub/brezen/personalni_strategie_n a_evropskem_trhu.pdf

Holátová, D., Doležalová, V., Březinová, M. et al. (2018). Human resource management in small and medium enterprises. Žilina: Georg.

Huang, T.C. (2000). Are the human resource practices of effective firms distinctly different from those of poorly performing ones? Evidence from Taiwanese enterprises. International Journal of Human Resource Management, 11 (2), 436-451.

Huselid, M. A., Becker, B. E., \& Beatty, R. W. (2005). The workforce scorecard: Managing human capital to execute strategy. Boston, MA: Harvard Business School Press Huselid, M.A., \& Becker, B.E. (2011). Bridging micro and macro domains: workforce differentiation and strategic human resource management. Journal of Management, 37, 421-428.

Charvát, J. (2006). Business strategy for practice. Praha: Grada.

Chiang, F.T., Chow, H.S., \& Birtch, T. A. (2010). Examining human resource outsourcing in Hong Kong. The International Journal of Human Resource Management, 21 (15), 2762-2777.

Chung, D.S., Jung, H.W., Baek, S.J., \& Lee, H.O. (2008). The impacts of strategic orientation and HRM systems on firm performance. International Journal of Business Strategy, 8 (2), 82-88.

Keller, G. (2014). Statistics for Management and Economics. Stamford, CT, USA : Cengage Learning: South-Western College Pub.

Khatri, N. (2000). Managing human resource for competitive advantage: A study of companies in Singapore. International Journal of Human Resource Management, 11 (2), 336-366.

Kinange, U.M., \& Murugaiah, V. (2011). Human resource outsourcing: a new mantra for business sustenance. International Conference on Asia Pacific Business Innovation \& Technology Management. In 
Procedia - Social and Behavioral Sciences, 25, 227-232.

Koubek, J. (2007). Human resource management. Praha: Management Press.

Larsen, H.H., \& Brewster, C. (2003). Line management responsibility for HRM: What is happening in Europe? Employee Relations, 25 (3), 228-244.

Lengnick-Hall, M.L., Lengnick-Hall, C.A., Andrade, L., \& Drake. B. (2009). Strategic human resource management: the evolution of the field. Human Resource Management Review, 19 (2), 64-85.

Mankelow, G. (2008). Social responsibility paradox of small business human resource management practices, The International Journal of Human Resource Management, 19 (12), 2171-2181.

Marlow, S. (1998). So much opportunity - so little take up: the case of training in small firms. Small Business and Enterprise Development, 5 (1), 38-47.

Martín-Alcázar, M., Romero-Fernández, P.M., \& Sánchez-Gardey, G. (2005). Strategic human resource management: Integrating the universalistic, contingent, configurational and contextual perspectives. The International Journal of Human Resource Management, 16 (5), 633-659.

McEvoy, G.M., \& Buller, P.F. (2013). Human resource management practices in mid-sized enterprises. American Journal of Business, 28 (1), 86-105.

Meloun, M., Militký, J., \& Hill, M. (2012). Statistical Analysis of Multidimensional Data in Examples. Praha: Academia.

Mihajlović, I. (2014). Possibilities for development of business cluster network between SMEs from Visegrad countries and Serbia. Serbian Journal of Management, 9 (2), 145-148.

Mihajlović, I., Voza, D., Milošević, I., \&
Durkalić, D. (2016). Environmental awareness as a universal European value. Serbian Journal of Management, 11 (2), 149-153.

Milliman, J., \& Clair, J. (1996). Best environmental HRM practices in the U.S. In W. Wehrmeyer (Ed.), Greening people: Human resources and environ-mental management (pp. 49-73). Sheffield, UK: Greenleaf Publishing.

Nankervis, A., \& Stanton, P. (2011). Linking strategic HRM, performance management and organizational effectiveness: perceptions of managers in Singapore. Asia Pacific Business Review, 17 (1), 67-84.

$\mathrm{Ng}$, E., Lyons, S.T., \& Schweitzer, L. (Eds.). (2012). Managing the new workforce: International perspectives on the millennial generation. Cheltenham, UK: Edward Elgar Publishing.

OECD. (2005). Small and medium sized enterprises and entrepreneurship outlook. OECD: Paris.

Ok, S.T. (2011). International outsourcing: Empirical evidence from the Netherlands. Journal of Business Economics and Management, 12 (1), 131-143.

Paauwe, J. (2004). HRM and performance: Achieving long term viability. Oxford: Oxford University Press.

Pech, M., \& Vaněček, D. (2018). Methods of lean production to improve quality in manufacturing. Quality Innovation Prosperity, 22(2), 1-15. https://doi.org/10.12776/qip.v22i2.1096

Ramus, C.A., \& Steger, U. (2000). The roles of supervisory support behaviors and environmental policy in employee "Ecoinitiatives" at leading-edge European companies. The Academy of Management Journal, 43 (4), 605-626.

Richard, O.C., \& Johnson, N.B. (2001). 
Understanding the impact of human resource diversity practices on firm performance. Journal of Managerial Issues, 13 (2), 177-195.

Robbins, S.P., \& Coulter, M. (2017). Management. Pearson.

Sheehan, C., \& Cooper, B.K. (2011). HRM outsourcing: the impact of organisational size and HRM strategic involvement. Personnel Review, 40 (6), 742-760.

Schuler R.S., Jackson S.E., \& Storey, J. (2001). HRM and its link with strategic management. In: J. Storey (ed.): Human Resource Management: A Critical Text (pp 114-130). London: Thomson Learning.

Sondhi, V., \& Nirmal, P.S. (2013). Strategic Human Resource Management: A Reality Check. Review of Management, 3 (1/2), 4-10.

Spellman, F.R., \& Whiting, N.E. (2014). Handbook of mathematics and statistics for the environment. Boca Raton: CRC Press, Taylor \& Francis Group.

Stanton, P., \& Nankervis, A. (2011). Linking strategic HRM, performance management and organizational effectiveness: Perceptions of managers in Singapore. Asia Pacific Business Review, 17, 67-84.

Susomrith, P., \& Brown, A. (2013). Motivations for HR outsourcing in Australia. International Journal of Human Resource Management, 24 (4), 704-720.

Ulrich, D., Younger, J., \& Brockbank, W. (2008). The twenty-first-century HR organization. Human Resource Management, 47 (4), 829-50.

Urbano, D., \& Yordanova, D. (2008). Determinants of the adoption of HRM practices in tourism SMEs in Spain: an exploratory study. Service Business, 2 (3), 167-185.
Vlachos, I. (2008). The effect of human resource practices on organizational performance: evidence from Greece. International Journal of Human Resource Management, 19 (1), 74-97.

Volek, T., \& Novotná, M. (2016). Labour Productivity as a Factor of Sector Competitiveness. 10th International Days of Statistics and Economics, 1997-2006.

Wager, T. (1998). Determinants of human resource management practices in small firms: some evidence from Atlantic Canada. J Small Bus Manag, 36 (2),13-23.

Walker, I. (2010). Research Methods and Statistics. Houndmills, Basingstoke, Hampshire; New York, NY: Palgrave.

Wang, D.S., \& Shyu, Ch. (2008). Will the strategic fit between business and HRM strategy influence HRM effectiveness and organizational performance? International Journal of Manpower, 29 (2), 92-110.

Westerman, J.W., Bergman, J.Z., Bergman, S.M., \& Daly, J.P. (2011). Are universities creating millennial narcissistic employees? An empirical examination of narcissism in business students and its implications. Journal of Management Education, 36 (1), 5-32.

Woodrow, C., \& Guest, D.E. (2014). When good HR gets bad results: exploring the challenge of HR implementation in the case of workplace bullying. Human Resource Management Journal, 24 (1), 3856.

Wright, P.M., Snell, S.A., \& Dyer, L. (2005). New models of strategic HRM in a global context. The International Journal of Human resource Management, 16 (6), 875881. 